\title{
Thermal Abuse Studies on Lithium Ion Rechargeable Batteries
}

\author{
E. Peter Roth, Chris C. Crafts, Daniel H. Doughty \\ Sandia National Laboratories, P.O. Box 5800 MS0613, Albuquerque, NM 87185-0613
}

\begin{abstract}
The thermal stability of Li-ion cells with intercalating carbon anodes and metal oxide cathodes was measured as a function of state of charge and temperature for two advanced cell chemistries. Cells of the 18650 design with $\mathrm{Li}_{x} \mathrm{CoO}_{2}$ cathodes (commercial SONY cells) and $\mathrm{Li}_{x} \mathrm{Ni}_{0.85} \mathrm{Co}_{0.15} \mathrm{O}_{2}$ cathodes were measured for thermal reactivity in the open circuit cell condition. Calorimetric techniques of differential scanning calorimetry (DSC) and accelerating rate calorimetry (ARC) were used to characterize these cells in both full cell configuration and as individual electrode components. The effects of thermal aging on cell thermal response were also investigated.
\end{abstract}

\section{Introduction}

Lithium-ion batteries (organic liquid electrolyte) have an advanced battery chemistry that exhibits superior performance characteristics to virtually all other rechargeable battery systems at room temperature. Consequently, this system is experiencing unparalleled growth and growth potential. These batteries demonstrate enhanced safety over the lithium metal systems that are subject to internal short circuits due to dendrite formation at the lithium metal surface after repeated cycling. The Li-ion cells use a carbon matrix for the intercalation of the $\mathrm{Li}$ ions at the anode in the charged state and use a metal oxide for $\mathrm{Li}$ ion intercalation at the cathode in the discharged state. This interchange of $\mathrm{Li}$ ions is referred to as a "rocking chair" cell. The formation of the active layers of each electrode material requires the use of polymeric binder material and conductivity enhancing additives. The electrolytes usually consist of a mixture of carbonate-based solvents and a $\mathrm{Li}$ salt. The lifetime and safety of these cells depends on the thermal stability of these active layer mixtures in the presence of electrolyte solution.

Calorimetric techniques are useful in measuring the thermal performance of actual cells under operating conditions and for determining the reactivity of the cell components which contribute to this performance. Accelerating rate calorimetry (ARC) can determine the thermal self heating rate of cells under adiabatic conditions for different charge states. This intrinsic cell property is critical in the design of safe battery systems. Examination of cell components and cell starting materials by differential scanning calorimetry (DSC) determines the thermal contributions of each cell element as a function of temperature and electrochemical state.

We have used these techniques to characterize two $\mathrm{Li}$-ion cell chemistries using $\mathrm{Li}_{\mathrm{x}} \mathrm{CoO}_{2}$ and $\mathrm{Li}_{\mathrm{x}} \mathrm{Ni}_{0.85} \mathrm{Co}_{0.15} \mathrm{O}_{2}$ cathodes. In this study, we measured the thermal stability of these cells as a function of state of charge (SOC) and after aging/cycling. We identified the source of the primary thermal reactions.

\section{Experimental}

We measured commercial SONY cells (US18650S STG) which had nominal 1.2 Ah capacity at $1 \mathrm{C}$ rate. The SONY-type cells consist of $\mathrm{Li}_{x} \mathrm{CoO}_{2}$ as the active cathode and $\mathrm{Li}_{x} \mathrm{C}_{6}$ intercalating carbon (coke) as the active anode using PVDF as the binder material (1). The electrolyte is a mixture of the carbonate-based solvents propylene carbonate (PC):dimethyl carbonate (DMC) with $\mathrm{LiPF}_{6}$ as the ionic salt.

The cells with $\mathrm{Li}_{x} \mathrm{Ni}_{0.85} \mathrm{Co}_{0.15} \mathrm{O}_{2}$ cathodes were prepared in the 18650 configuration and had a nominal capacity of $0.9 \mathrm{Ah}$ (1C rate). These cells are referred to as GEN1 Cells. The cathodes and MCMB carbon anodes were prepared using 


\section{DISCLAIMER}

This report was prepared as an account of work sponsored by an agency of the United States Government. Neither the United States Government nor any agency thereof, nor any of their employees, make any warranty, express or implied, or assumes any legal liability or responsibility for the accuracy, completeness, or usefulness of any information, apparatus, product, or process disclosed, or represents that its use would not infringe privately owned rights. Reference herein to any specific commercial product, process, or service by trade name, trademark, manufacturer, or otherwise does not necessarily constitute or imply its endorsement, recommendation, or favoring by the United States Government or any agency thereof. The views and opinions of authors expressed herein do not necessarily state or reflect those of the United States Government or any agency thereof. 


\section{DISCLAIMER}

Portions of this document may be illegible in electronic image products. Images are produced from the best available original document. 
PVDF binder and the cell electrolyte was (1M) $\mathrm{LiPF}_{6}$ /ethylene carbonate (EC):diethylcarbonate (DEC) $(1: 1)$.

The ARC measurements were performed using an ARC-2000 accelerating rate calorimeter (Coloumbia Scientific Industries, Austin, TX) using a specially designed holder for the 18650 cells which allowed simultaneous monitoring of cell voltage. The maximum cell temperature was limited to $140^{\circ} \mathrm{C}$ for the initial ARC runs and later limited to $160^{\circ} \mathrm{C}$ for the remainder of the cells, which was above the vent temperature of the cells. DSC analysis of cell components was performed using a DSC 2920 (TA Instr., New Castle, DE) up to a temperature of $400^{\circ} \mathrm{C}$ in sealed aluminum pans.

\section{Results and Discussion}

Initial safety thermal ramps were performed on the cells to determine the temperature ranges of the major thermal events. Figure 1 shows sequential pictures of a cell (GEN1) at $80 \%$ SOC ramped in a thermal block up to $200^{\circ} \mathrm{C}$. The flammable electrolyte is seen to freely flow from the cell at about $150^{\circ} \mathrm{C}$ followed by explosive decomposition at $200^{\circ} \mathrm{C}$. In order to characterize this behavior under more controlled conditions, the cells were measured in the ARC apparatus.

SONY cells were measured at states of charge of $0 \%, 50 \%, 75 \%, 90 \%$ and $100 \%$. The ARC data for these cells, shown offset in Figure 2, show how the onset temperature of accelerating heat rate decreases with increasing SOC. A threshold of $0.02^{\circ} \mathrm{C} / \mathrm{min}$ is used to define sustained self heating. Accelerating self heating began as high as $130^{\circ} \mathrm{C}$ for the $0 \%$ SOC cell and decreased to about $80^{\circ} \mathrm{C}$ for the $100 \%$ SOC cell. Drops in cell voltage were associated with sudden decreases in the heating rate, suggesting that cell venting occurred at those temperatures. Venting did not stop the accelerating self heating of these cells and thus did not provide a thermal safety mechanism.

The ARC data for the $\mathrm{Li}_{\mathrm{x}} \mathrm{Ni}_{0.85} \mathrm{Co}_{0.15} \mathrm{O}_{2}$ cells are shown in Figure 3. The data sets are offset by $0.025^{\circ} \mathrm{C} / \mathrm{min}$ for clarity. These cells were measured at $5 \%, 50 \%, 75 \%, 90 \%$ and $100 \%$ SOC. In addition, a cell ( $100+\%$ SOC) was overcharged by $0.1 \mathrm{~V}$ to $4.2 \mathrm{~V}$ to measure sensitivity of the cells under abnormal conditions. It is clear that these cells are more thermally stable than the SONY cells. Continuous self generated heating only occurred for a SOC of $75 \%$ or greater and began around $80^{\circ} \mathrm{C}$, independent of SOC. Venting in these cells occurred at $130^{\circ} \mathrm{C}$ independent of the SOC. A region of thermal output was observed at lower temperatures $\left(40^{\circ} \mathrm{C}-70^{\circ} \mathrm{C}\right)$ which was sensitive to the cell potential, occurring at lower temperatures with increasing potential (SOC). A source of heat for the initiation of accelerating self heating (thermal runaway) has been identified in the anode material as the decomposition of the solid electrolyte interphase (SEI) layer and subsequent reaction of the $\mathrm{Li}_{\mathrm{x}} \mathrm{C}_{6}$ with the solvent (2-4). Our results are consistent with this interpretation for both types of cells.

It has been shown that the SEI layer formed during initial lithiation transforms over time, reacting with $\mathrm{HF}$ in the electrolyte $(5,6)$. This layer changes from a primarily organic layer to a more stable inorganic layer composed mostly of LiF. This new layer can affect the rate of thermal decomposition of the remaining SEI layer. We measured the effect of aging in the SONY and GEN1 cells by holding them for increasing periods at elevated temperatures. Figure 4 shows the ARC data for the SONY aged cells $\left(25^{\circ} \mathrm{C}\right.$ $70^{\circ} \mathrm{C}$ ). Aging is seen to result in a loss of the low-temperature reactions. With increased aging temperature and time the onset of thermal runaway shifts to higher temperature but all cells showed a sharp rise in heating rate around $115^{\circ} \mathrm{C}$ followed by accelerating heating rate due to continued electrolyte reduction.

Figure 5 show ARC data for GEN1 cells aged/cycled at increasing temperatures $\left(25^{\circ} \mathrm{C}\right.$ $60^{\circ} \mathrm{C}$ ). These cells initially showed a reduction in thermal output as a result of aging at $40^{\circ} \mathrm{C}$. However, with aging at the higher temperatures of $50^{\circ} \mathrm{C}-60^{\circ} \mathrm{C}$ the cells behaved similarly to fresh cells. These results suggest that the $\mathrm{LiF}$ layer that has been seen to form on the anodes may be very delicate. Although $\mathrm{LiF}$ will not dissolve at these temperatures, the morphology of the layer may depend on aging/cycling temperature and the surface characteristics of the carbon particles. If the inorganic layer is discontinuous and cracked, the electrolyte can penetrate near to the carbon particle and intercalated $\mathrm{Li}$ can continue to form new SEI with the associated heat generation.

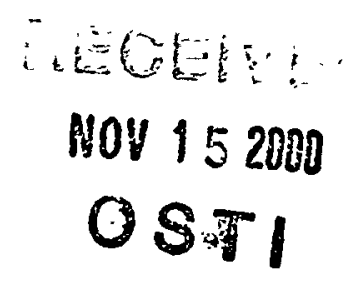




\section{Conclusions}

Calorimetric analysis has identified cell and component reactions in $\mathrm{Li}$-ion cells that contribute to the complex thermal response of these cells. Initial low-temperature reactions result from conversion of the anode SEI layer to more stable phases. This reaction can lead to thermal runaway in cells in the fully charged state. Aging results in partial completion of these reactions, which change the composition and morphology of the SEI layer. Aging does not result in increased thermal reactivity and may result in passivation of the SEI layer under certain conditions.

\section{Acknowledgements}

The author thanks GiGi Gonzales for sample preparation, Bob Patton for the ARC measurements and Jennifer Dobbs for the DSC measurements. We acknowledge the support of DOE Office of Advanced Automotive Technology through the PNGV Advanced Technology Development (ATD) High Power Battery Development Program. Sandia National Laboratories is a multiprogram laboratory operated by Sandia Corporation, a Lockheed Martin Company, for the United States Department of Energy under contract DE-AC0494AL85000.

\section{References}

1. K. Ozawa, Solid State Ionics, 69, 212 (1994).

2. U. von Sacken, E. Nodwell, A. Sundher, and J. R. Dahn, J. Power Sources, 54, 240-245 (1995).

3. M. N. Richard and J. R. Dahn, J. Electrochem. Soc., 146, 2068-2077 (1999).

4. M. N. Richard and J. R. Dahn, J. Electrochem. Soc., 146, 2078-2084 (1999).

5. D. Aurbach, Y. Ein-Ely and A. Zaban, $J$. Electrochem. Soc., 141, LI (1994).

6. T. Sato, M. Deschamps, H. Suzuki, H. Ota, H. Asahina and S. Mori, Matl. Res. Soc. Symp. Proc. Vol. 496, 457 (1998). 


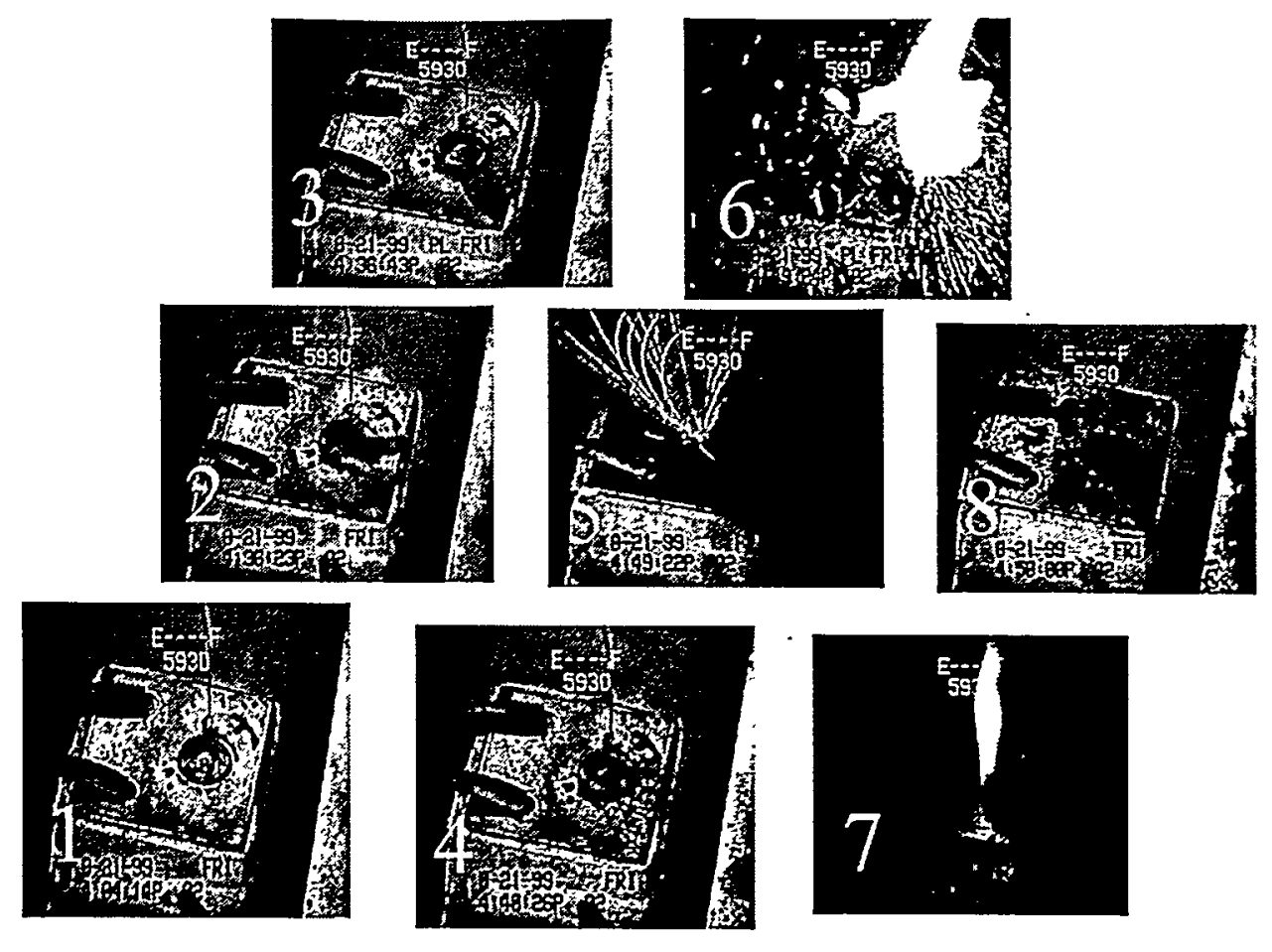

$1 \quad 2-4 \quad 5-7$

Heat Block Test to $200 \mathrm{C}$ on ATD GEN 1 at $80 \%$ SOC

Cell P154 C-1002 90409-116. Rocketed away w/sparks, stayed intact.

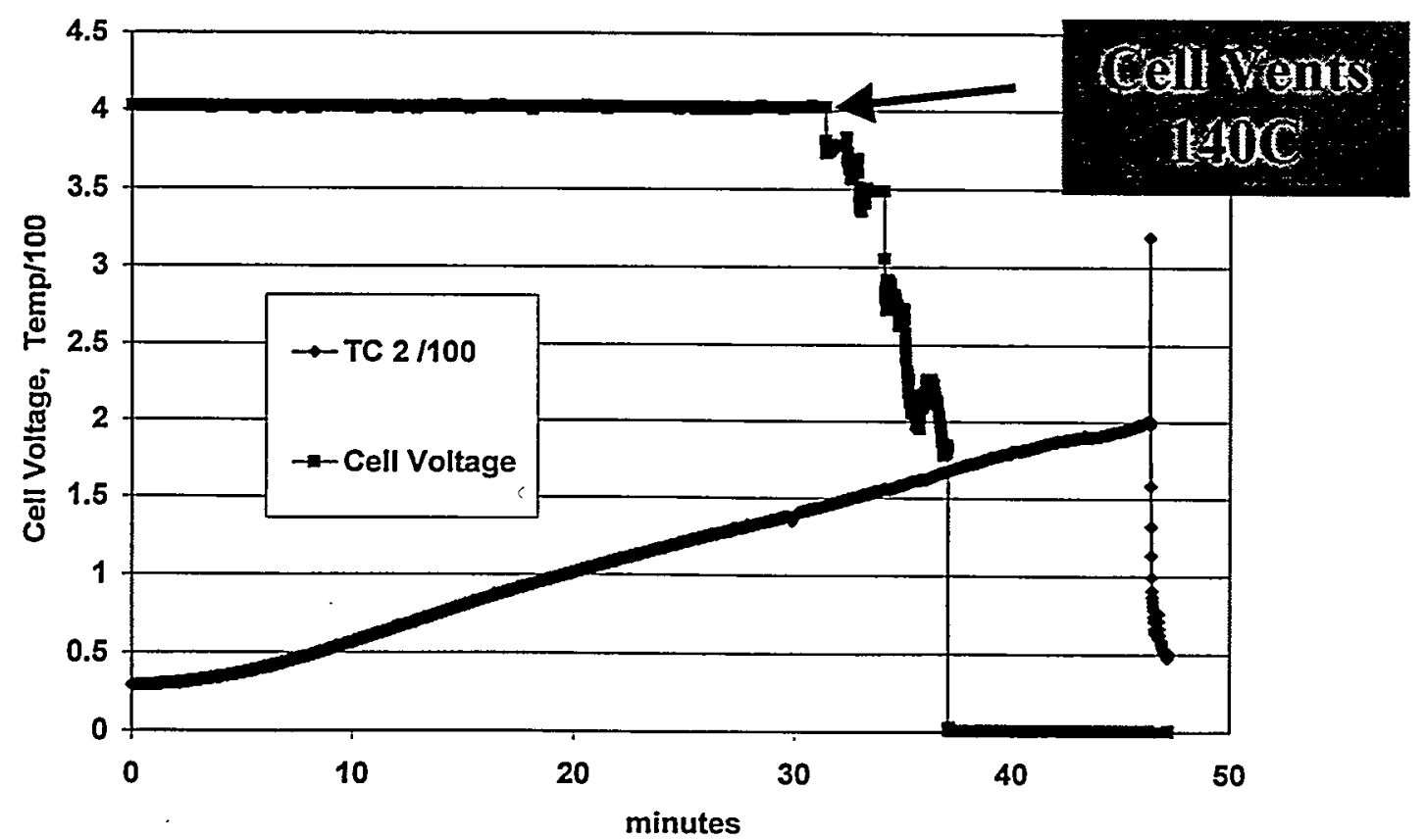

Figure 1. Temperature ramp of $\mathrm{Li}_{x} \mathrm{Ni}_{0.85} \mathrm{Co}_{0.15} \mathrm{O}_{2}$ cell (GEN1) to $200^{\circ} \mathrm{C}$. 


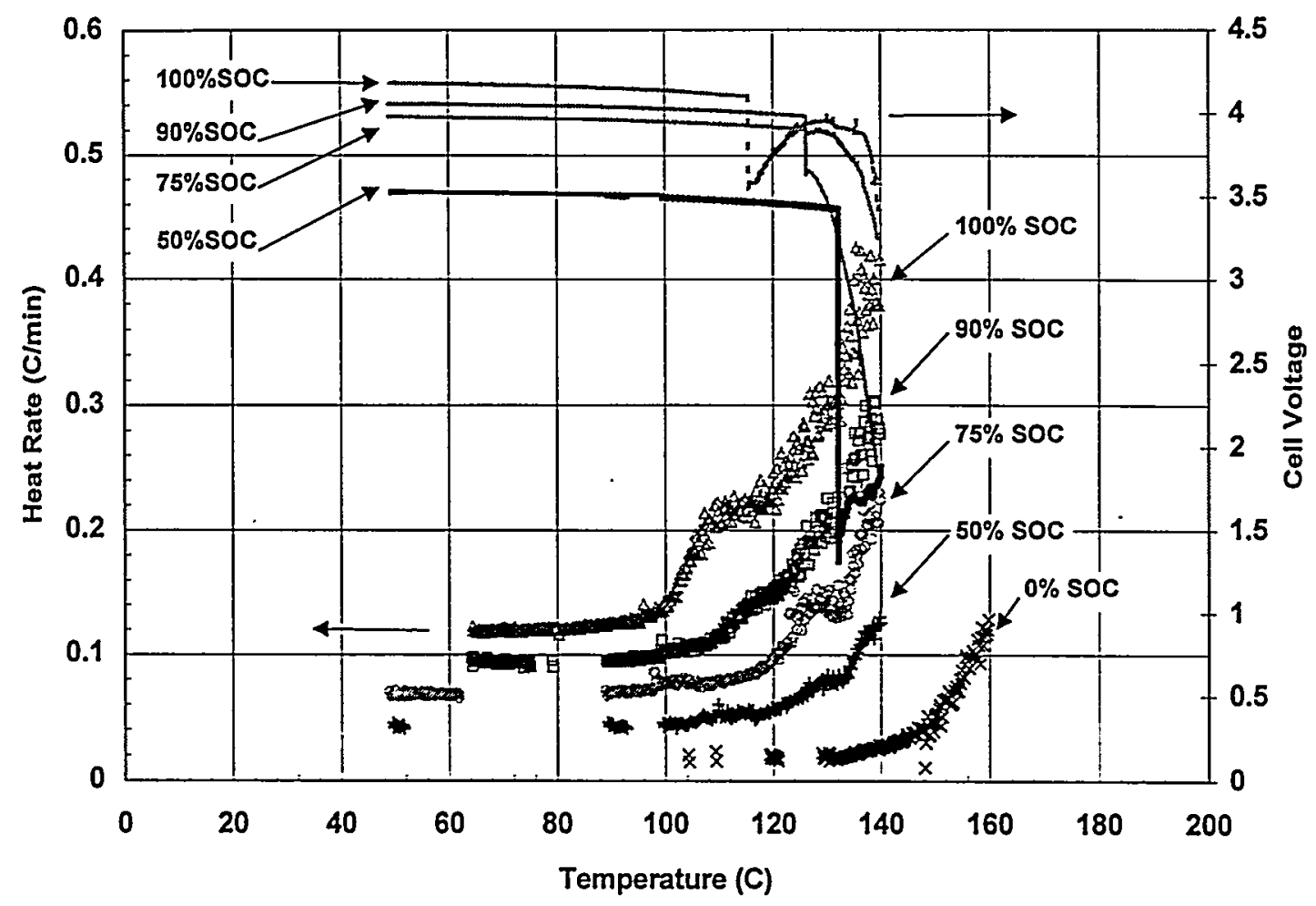

Figure 2. ARC data for SONY Li-ion cells as function of state of charge.

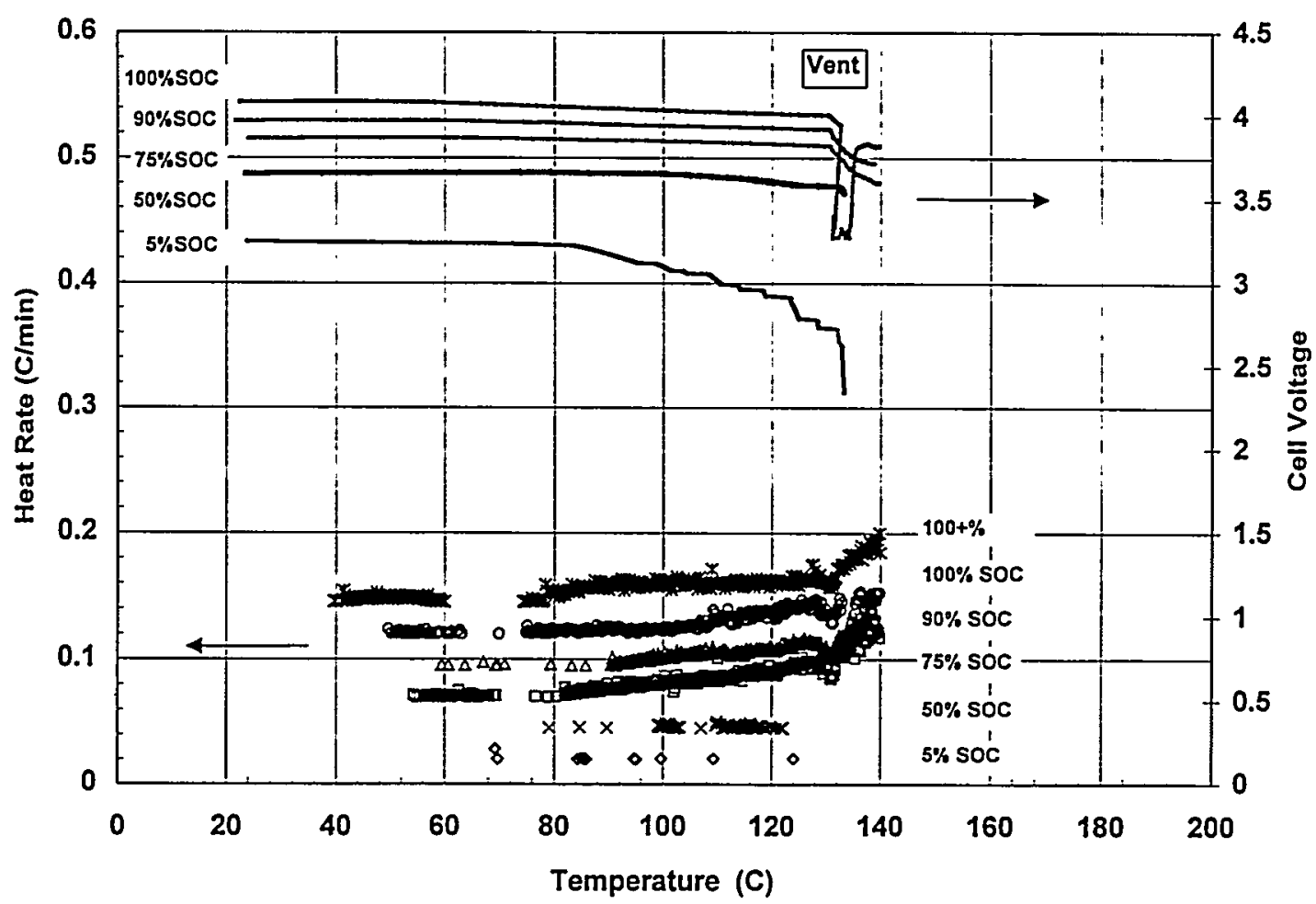

Figure 3. ARC data for GEN1 Li-ion cells as function of state of charge. 


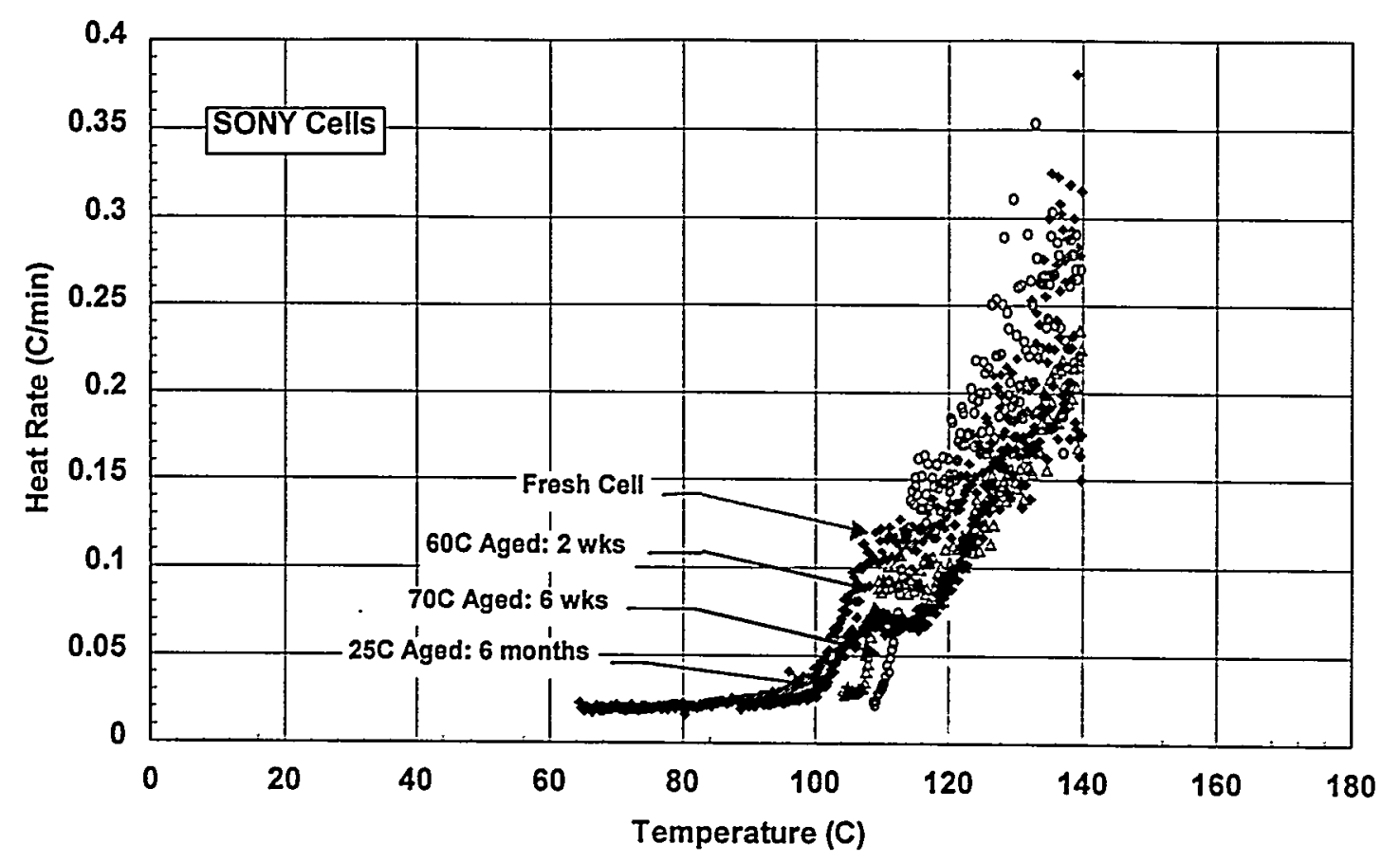

Figure 4. ARC data for aged SONY cells.

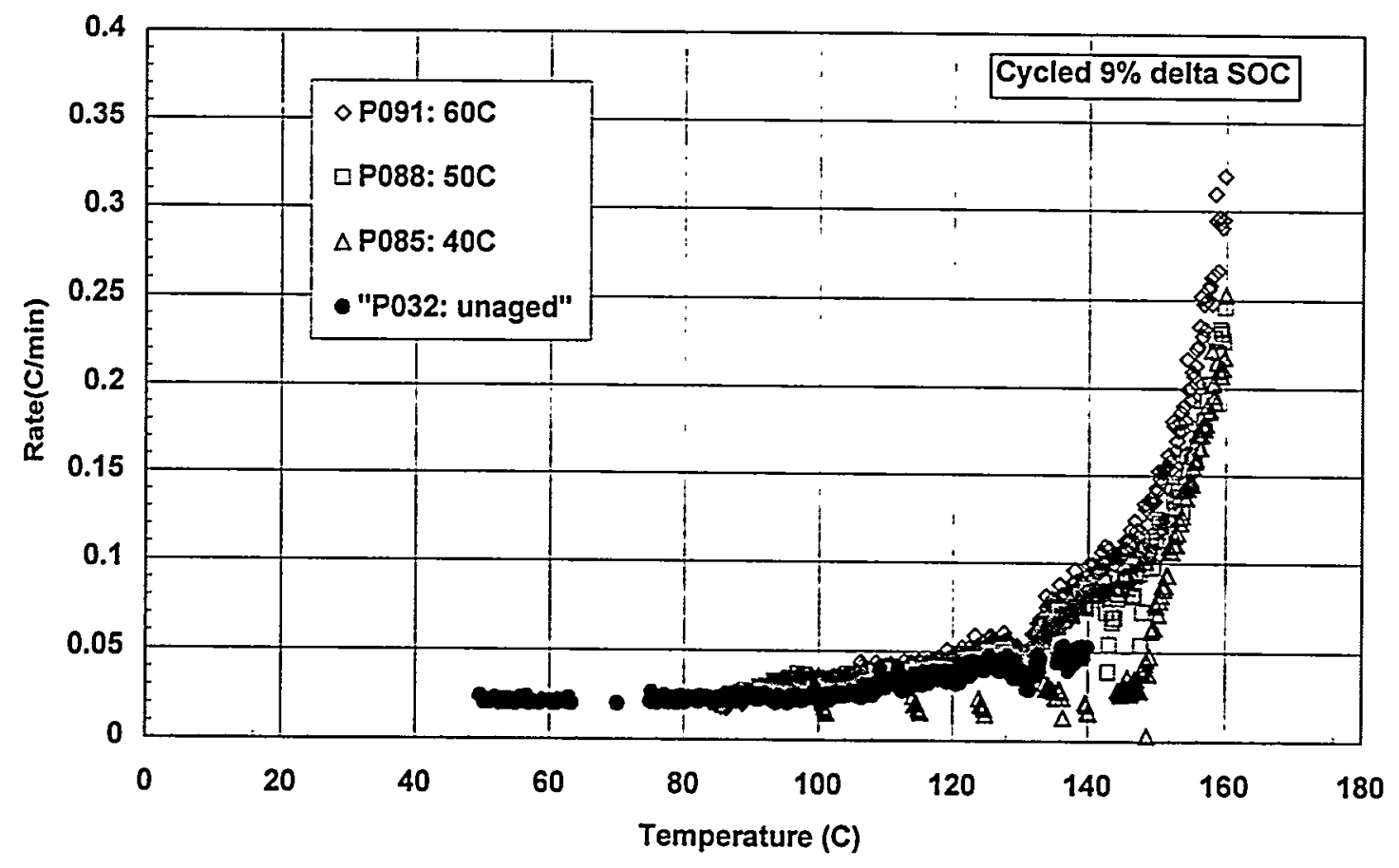

Figure 5. ARC data for age GEN1 cells. 